\title{
The effectiveness of curry leaves (Murayya koenegii) on the physical quality of chicken meatball
}

\author{
Peni Patriani ${ }^{1 *}$ and Nezsa Laras Apsari ${ }^{2}$ \\ ${ }^{1}$ Department of Animal Husbandry, Faculty of Agriculture, Universitas Sumatera Utara, Jl. \\ Dr. A. Sofian, Medan, 20155, Sumatera Utara, Indonesia \\ ${ }^{2}$ Faculty of Animal Husbandry, Universitas Padjajaran, Hegarmanah Jatinangor, Sumedang, \\ 45363, Jawa Barat, Indonesia
}

\begin{abstract}
Curry leaves (Murayya koenegii) are spices commonly used as a flavouring in Indonesian cuisine. Curry leaves contain antioxidants, antitherapeutic agents, and inhibitors of pathogenic bacteria. The purpose of this study was to observe the effectiveness of adding curry leaves to chicken meatballs at 48 hours of storage. The research design used in this study was a completely randomized design with 4 treatments and 5 replications. The treatments consist of $\mathrm{P} 0$ : meatball without curry leaves $0 \%$; P1: meatball + dried curry leaves $2 \%$; P2: Meatball + dried curry leaves 4\%; P3: Meatball + dried curry leaves 6\%. After boiling, the meatballs were stored at $27^{\circ} \mathrm{C}$ for 48 hours to be tested for physical quality. The results showed that the addition of curry leaves to the meatball mixture had a significant effect $(\mathrm{P}<0.05)$ on the physical quality among others $\mathrm{pH}$, water content, cooking loss, tenderness, colour scale of brightness (L), and redness $\left(\mathrm{a}^{*}\right)$. However, it had no significant effect on the yellowish colour $\left(b^{*}\right)$. Curry leaves can also inhibit early rotten in chicken meatballs for 48 hours of storage. It was concluded that the addition of curry leaves was effective in improving the physical quality of chicken meatballs
\end{abstract}

\section{Introduction}

Chicken meatball is a product from the mixture of ground beef with flour and spices then formed into balls and boiled. In Indonesia, meatball is a very popular favourite food. The level of meatball consumption is in line with the development of the number of producers who process various innovations. At this time, consumer demand has increased for processed meat products that are healthier because using natural ingredients. These consumer demands encourage the development of processed meat products with healthier bioactive compounds [1]. Bioactive compounds can come from ingredients derived from plants so that they can be used in the formulation of processed meat products.

\footnotetext{
* Corresponding author: Penipatriani@usu.ac.id
} 
Curry leaves or Murayya koenegi contain anti-inflammatory, anti-bacterial, and antidiabetic compounds [2]. According to [3] curry leaves have properties that can treat diseases associated with pathogenic bacteria. Curry leaves contain biguanides such as metformin that are used for type 2 diabetes treatment [4]. According to [5] curry leaves are therapeutic agents and effective in inhibiting Escherichia coli, Staphylococcus aureus, Vibrio cholerae, Klebsiella pneumonia, Salmonella typhi, and Bacillus subtilis which are comparable to commercial antibiotics chloramphenicol, streptomycin, and gentamicin. Antioxidant protein from curry leaves showed antibacterial activity against pathogenic bacteria. In addition, curry leaves also have anticancer activity [6].

The study was to determine the effectiveness of curry leaves on the physical quality of chicken meatballs at 48 hours of storage. Physical quality test on meatballs is a very important factor before food is consumed. If the quality of the meatball meets the criteria set by the Indonesian National Standard, the meatball is safe for consumption. The benefit of this research is as a source of information about the physical quality of meatballs with the addition of curry leaves during a 48 hours shelf life.

\section{Methods}

\subsection{Material}

Making chicken meatball based on [7] using 1000 grams of chicken meat, 100 grams of casasava flour, 1 egg, 6 grams of pepper, 5 pieces of Garlic , 6 grams sodium tripolyphosphate, 10 grams salt, ice, dried curry leaves $2 \%, 4 \%$, and $6 \%$.

\subsection{Procedure for Making Chicken Meatball}

The chicken meat is ground with ice cubes, then all the spices are mashed and mixed in the chicken meat mixture. The meat dough is added with tapioca flour, eggs, STTP, and curry leaves. The dough is moulded into a round shape and then boiled for 20 minutes in $100^{\circ} \mathrm{C}$ water.

\subsection{Procedure for Measuring pH Value}

The $\mathrm{pH}$ value is the degree of acidity measured using the Amtast AMT16M meat $\mathrm{pH}$ meter by immersing the sensor needle on the $\mathrm{pH}$ meter into Aquadest and $\mathrm{KCl}$. Then the sensor needle is inserted into the meatball for 1 minute [8]

\subsection{Procedure for Measuring Cooking loss}

Cooking loss measurement method using CSIRO [8]. Meatball dough is weighed and put into a plastic bag and then boiled in water at a temperature of $80-90^{\circ} \mathrm{C}$. After being boiled, it is weighed again after the meatballs are cold.

\subsection{Procedure for Measuring Water Content}

Measuring the water content of the meatball using the Amtast DM300R water content meter. The water content meter is set first with a scale of 6-7 then wait until the number display on the LCD layer becomes 0 . Insert the sensor needle into the meatball sample [9] 


\subsection{Procedure for Measuring Colour}

Measuring meat colour using the Amtast AMT501U Colorimeter. Calibrate the sensor tip on the black and white stabilizer. Aim the sensor tip by pressing the button so that the beam of light reaches the target of the meatball sample correctly [10]

\subsection{Procedure for Measuring Tenderness}

The tenderness of chicken meatballs is measured using a Penetrometer [11]. Slice the meatball with a size of $1 \times 1 \times 1 \mathrm{~cm}$ then place them at the bottom of the penetrometer. Press the penetrometer lever for 10 seconds then note the scale that appears on the instrument

\subsection{Measuring Early Sign of Rotten}

Measurement of the early signs of meat rotten using the Postma test. As much as 1 gram of meatball sample in $10 \mathrm{ml}$ of water left for 10 minutes. Then mix $100 \mathrm{mg}$ of $\mathrm{MgO}$ and heat to $50^{\circ} \mathrm{C}$. Place the sample in a petri dish with a lid on the sample. Put in the litmus paper and glue it back together. Wait for 10 minutes and watch the colour change on the litmus paper [12-13].

\subsection{Research Design}

This study used a completely randomized design with 4 treatments and 5 replications if there were significantly different values followed by the Duncan test.

P0 : meatball without curry leaves as control or $0 \%$

P1 : meatball + dried curry leaves $2 \%$

P2 : meatball + dried curry leaves $4 \%$

$\mathrm{P} 3$ : meatball + dried curry leaves $6 \%$

The meatballs were stored at $27^{\circ} \mathrm{C}-31^{\circ} \mathrm{C}$ for 48 hours and then each sample was measured using a predetermined measurement procedure

\section{Results and Discussions}

The results of physical quality measurement of meatball sample in the study consisting of the $\mathrm{pH}$ value, water content, cooking loss, colour, and early signs of meat rot can be seen in the table 1 below.

Table1. Physical quality of chicken meatballs with dried curry leaves

\begin{tabular}{|l|c|c|c|c|}
\hline Physical Quality & P0 & P1 & P2 & P3 \\
\hline pH Value & $6.52 \pm 0.25^{\mathrm{a}}$ & $6.28 \pm 0,12^{\mathrm{a}}$ & $6.17 \pm 0.21^{\mathrm{b}}$ & $6.13 \pm 0.18^{\mathrm{b}}$ \\
\hline Water content & $70.5 \pm 1.22^{\mathrm{a}}$ & $65.2 \pm 1.10^{\mathrm{b}}$ & $64.5 \pm 1.42^{\mathrm{b}}$ & $64.8 \pm 1.13^{\mathrm{b}}$ \\
\hline Cooking loss & $22.7 \pm 3.83^{\mathrm{a}}$ & $19.6 \pm 1.46^{\mathrm{ab}}$ & $14.4 \pm 1.44^{\mathrm{b}}$ & $14.8 \pm 2.15^{\mathrm{b}}$ \\
\hline Colour & & & & \\
\hline $\mathrm{L}$ & $31.6 \pm 2.14^{\mathrm{a}}$ & $31.3 \pm 1.52^{\mathrm{a}}$ & $30.5 \pm 1.23^{\mathrm{a}}$ & $21.62 \pm 3.3^{\mathrm{b}}$ \\
\hline $\mathrm{a}$ & $6.2 \pm 2.21^{\mathrm{a}}$ & $3.21 \pm 1.29^{\mathrm{b}}$ & $3.10 \pm 1.72^{\mathrm{b}}$ & $3.65 \pm 2.31^{\mathrm{b}}$ \\
\hline $\mathrm{b}$ & $8.23 \pm 1.10$ & $9.52 \pm 2.09$ & $9.63 \pm 1.48$ & $9.09 \pm 1.12$ \\
\hline $\begin{array}{l}\text { Tenderness } \\
\text { (mm/g/det) }\end{array}$ & $0.0462 \pm 0.0033^{\mathrm{a}}$ & $0.0485 \pm 0.0072^{\mathrm{a}}$ & $0.0574 \pm 0.0062^{\mathrm{b}}$ & $0.0501 \pm 0,0031^{\mathrm{ab}}$ \\
\hline Rotten Sign & Positive & Negative & Negative & Negative \\
\hline
\end{tabular}

The different notation shows real differences $(\mathrm{P}<0.05)$ 


\section{$3.1 \mathrm{pH}$ of Chicken Meatball}

The results showed that curry leaves had a significant $(\mathrm{P}<0.05)$ on the $\mathrm{pH}$ of chicken meatball. The highest average meat $\mathrm{pH}$ value was at $\mathrm{P} 0$ which was $6.52 \pm 0.25$ and the lowest was at $\mathrm{P} 2$ that was $6.17 \pm 0.21$. The $\mathrm{pH}$ values at $\mathrm{P} 0$ and $\mathrm{P} 1$ were significantly different from those at $\mathrm{P} 2$ and $\mathrm{P} 3$ on the $\mathrm{pH}$ of the meat. The decrease in the $\mathrm{pH}$ value occurred from P0, P1 and then decreased at P2 and P3. It can be affected by the basic ingredients used in making meatballs. Change in hydrogen balance as a result of the basic ingredients used. Following [14] that changes in the constituent materials in restructured meat can affect the $\mathrm{pH}$ value of the processed product. According to [15] the $\mathrm{pH}$ value of meatball is between 5.5-7.2. According to SNI or national standards used in Indonesia, the $\mathrm{pH}$ of meatballs is between 6-7. At the $\mathrm{pH}$ of the meatballs the research results were in the normal category. The $\mathrm{pH}$ of meatballs is related to the shelf life of meatballs. The lower the $\mathrm{pH}$ of the meatballs, the lower the microbial growth, thus extending the shelf life.

\subsection{Water Content of Chicken Meatball}

The percentage of water content in samples P0, P1, P2, and P3 were 70.5 \pm 1.22 , respectively; $65.2 \pm 1.10 ; 64.5 \pm 1.42$; and $64.8 \pm 1.13$. Results of analysis of variance showed that $\mathrm{P} 0$ had a significant effect $(\mathrm{P}<0.05)$ on $\mathrm{P} 1, \mathrm{P} 2$, and $\mathrm{P} 3$. It means that the addition of curry leaves can affect the percentage of the water content of chicken meatballs. According to [16] cooking in meatballs can reduce the water content in meatballs. The water content in this study was lower than [17] cooked meatballs had an average water content of $53.54 \%$. The percentage of meatball moisture according to the Indonesian National Standards Agency 01-3818-1995 is a maximum of 70.0\%. It means that the range of water content in the addition of curry leaves was normal. The percentage of moisture content in processed meat products meatballs may affect the storage time. High moisture content can increase microbial growth. The best treatment for the moisture content of chicken meatball was in P2 treatment with the addition of $4 \%$ curry leaves in the meatball dough

\subsection{Cooking Loss of Chicken Meatball}

The average percentage cooking loss in chicken meatballs in the study for P0, P1, P2, and P3 were $22.7 \pm 3.83 ; 19.6 \pm 1.46 ; 14.4 \pm 1.44$, and $14.8 \pm 2.15$, respectively. The highest percentage of cooking loss is at P0 or control, while the lowest percentage is at P2 and P3. Duncan's test results showed that $\mathrm{P} 0$ was significantly different $(\mathrm{P}<0.05)$ to the $\mathrm{P} 2$ and $\mathrm{P} 3$. It means the higher the addition of dried curry leaves to the dough, the slower the cooking loss in meatballs. The value of cooking loss in the control was higher than in the treatment. It is suspected that curry leaves powder can make the dough denser because dry curry leaves powder can absorb water when mixed with the dough. Before boiling, it can be seen that the dough in the treatment looks denser than the control (P1). According to [18] the use of powdered curry leaves did not affect the water holding capacity and did not affect the loss of nutrients in food. This means that curry leaves can maintain the protein content in the meatball dough so that the water holding capacity can be maintained and the cooking loss has a low percentage. Cooking loss in experimental samples within the normal range. According to [19] the percentage of cooking loss in meatballs with added gum is between $22.0-17.7 \%$. Cooking loss in meatballs with the addition of pomegranate is between $19.20 \%$ to $23.1 \%$ [20]. Cooking loss in this study was normal. The addition of curry leaves $4 \%(\mathrm{P} 2)$ and $6 \%(\mathrm{P} 3)$ in the meatball mixture was effective in reducing cooking loss. 


\subsection{Colour of Chicken Meatball}

The colour of chicken meatball after cooking at L (Light) is the brightness level of chicken meatball with the highest value at P1 that was $31.6 \pm 2.14$ and the lowest at P3 that was $21.62 \pm 3.3$. Duncan's test results showed that $\mathrm{P} 3$ was significantly different $(\mathrm{P}<0.05)$ against $\mathrm{P} 0, \mathrm{P} 1$, and $\mathrm{P} 2$. The higher the addition of curry leaves, the brightness level decreases. According to [21] the brightness level of the meatball is 32.80 while the addition of wheat meatball is between 34.75-38.04. In this study, the brightness level is lower. It can happen because the curry leaves powder is brownish so it can affect the brightness of the meatballs. However, with the addition of $2 \%(\mathrm{P} 1)$ and $4 \%$ (P2) curry leaves, the brightness level was higher so it is quite good if applied to chicken meatball dough. The $\mathrm{b}^{*}$ or yellowish colour scale showed no significant difference $(\mathrm{P}>0.05)$ between treatments. The lowest $\mathrm{b}^{*}$ colour scale was at P0 namely $8.23 \pm 1.10$ and the highest was at P2 and P1. The high yellow colour can be caused by carotenoid pigments present in plants [21]. A higher yellowish colour scale can also indicate the freshness of chicken or processed products. It means that the treatment with the addition of curry leaves during the 48-hour shelf life of the meatballs is still quite fresh. The reddish colour scale or $\mathrm{a}^{*}$ at $\mathrm{P} 0$ is $6.2 \pm 2.21$ while at $\mathrm{P} 1, \mathrm{P} 2$ and $\mathrm{P} 3$ are $3.21 \pm 1.29 ; 3.10 \pm 1.72 ; 3.65 \pm 2.31$. Duncan's test results showed that P0 was very significantly different from P1, P2, and P3. This means that P2 and P3 treatments were recommended in this study. The higher the red colour scale $\left(\mathrm{a}^{*}\right)$ showed that the meat or meatball has undergone a process of decay or become a carcass. It means that at P1, P2 and P3 showed the chicken meatball mixture with the addition of curry leaves can last for 48 hours.

\subsection{Tenderness of Chicken Meatball}

Meat tenderness is measured using a penetrometer that is determined by the amount of pressure or force required by the unit area $(\mathrm{mm} / \mathrm{g} / 10 \mathrm{~s})$ on meat or processed products [12]. The lowest value of meatball tenderness was at P0 which was $0.0462 \pm 0.0033$ and the highest tenderness was at P2 that was $0.0574 \pm 0.0062$. Based on Duncan's test, there was no significant difference between $\mathrm{P} 0(\mathrm{P}>0.05)$ to $\mathrm{P} 1$ but significantly different from $\mathrm{P} 2$. Tenderness can be affected by enzymes, heating, shelf life, and the use of fillers. The addition of curry leaves affects the tenderness of chicken meatballs as shown by the sample (P2) 4\%. In sample P3 tenderness decreased. This is supposedly due to the decreased water content causing the surface of the meatballs to become dry and somewhat hard. However, in this study, the addition of $4 \%$ curry leaves was good enough to increase the tenderness of chicken meatballs

\subsection{Early Rotten Sign of Chicken Meatball}

The results of the study were P0 that was stored for 48 hours the results were $(+)$ while the P1, P2, and P3 treatments obtained negative results (-). According to [15] curry leaves extract can extend the shelf life of meat for 3-5 days. According to [22] curry leaves extract $25 \%-50 \%$ can extend the shelf life of meat for 5-7 days. Postma test is used to determine the metabolism carried out by pathogenic microorganisms. Bacterial growth in this study showed that it could be inhibited by the addition of curry leaves. It can occur because bacterial growth is caused by the interaction of compounds in curry leaves with bacterial cell membranes, causing damage to the bacterial cell wall. According to [23] the content of flavonoids which are lipophilic as a cause of cell membrane damage in bacteria so that bacterial growth is inhibited. Bacterial growth that has been inhibited causes the shelf life of chicken meatballs to be longer than was 48 hours compared to the sample at P0. In this 
study, the P0 or control sample showed a $(+)$ result, which means that initial spoilage has occurred and the $\mathrm{pH}$ of the meat has become alkaline. In fresh meat, $\mathrm{NH} 3 \mathrm{OH}$ is not formed because free NH3 has not been formed, resulting in a change in the colour of the litmus paper. Early rot is usually characterized by the surface of the material being slimy and emitting a foul odour. Meanwhile, in the P1, P2, and P3 treatments, the initial decay process could be inhibited. Based on the results of research that curry leaves are effective as a preservative for chicken meatballs. In addition to this, the taste and aroma of meatballs using $4 \%$ curry leaf still show a taste that is acceptable to consumers.

\section{Conclusions}

The addition of curry leaves (Murayya koenegii) to the meatball mixture had a significant effect $(\mathrm{P}<0.05)$ on the physical quality among others $\mathrm{pH}$, water content, cooking loss, tenderness, colour scale of brightness $\left(\mathrm{L}^{*}\right)$, and redness $\left(\mathrm{a}^{*}\right)$. Curry leaves (Murayya koenegii) can maintain the $\mathrm{pH}$ Value and water content, increase tenderness, reduce cooking loss, maintain the colour of chicken meatballs at the addition of $4 \%$ (P2). Curry leaves (Murayya koenegii) can also inhibit spoilage in chicken meatballs for 48 hours of storage. Aaddition of 4\% curry leaves (Murayya koenegii) in P2 treatment was effective in improving the physical quality of chicken meatball

\section{References}

1. K. Verma, V. Pathak, V. P. Singh and P. Umaraw, Journal of Applied Animal Research, 44, 409-414 (2016)

2. R. Balakrishnan, D. Vijayraja, S.H. Jo, P. Ganesan, I. Su-Kim, and D.K Choi, Antioxidants (Basel, Switzerland), 9, 101 (2020)

3. I. Abuga, S.F Sulaiman, R. A. Wahab, K. L. Koii, M. S. Bahari, andA. Rasyad, European Journal of Integrative Medicine, 33 (2020).

4. V. Perla and S. S. Jayanty, Food Chemistry, 138, 1574-1580 (2013)

5. B. Mylarappa, B. L Ningappa, R. Dhananjaya, R. Dinesh, Harsha, and L. Srinivas, Food Chemistry. 118, 747-750 (2010)

6. S. K. Samanta, R. Kandimalla, B. Gogoi, K. N. Dutta, P. Choudhury, P. K. Deb, R. Devi, B. C. Pal, and N. C. Talukdar, Pharmacological Research, 129, 227-236 (2018)

7. P. Patriani, J. Hellyward, H. Hafid, N. L. Apsari and Hasnudi. Application of sweet basil (Ocimum basilicum) on physical and organolepict qualities of chicken meatballs. IOP Conf. Series: Earth and Environmental Science 782022083 (2021)

8. Soeparno. Ilmu dan Teknologi Daging [Meat Science and Technology]. (Gajahmada University Press, Yogyakarta, 1998)

9. H. Hafid, P. Patriani, Nuraini, S. H. Ananda. Marination technology using kandis acid (Garcinia xanthochymus) biomass to improve the physical quality of culled chicken meat. IOP Conf. Series: Earth and Environmental Science 749012003 (2021)

10. H. Camilla, Trinderup, A. Dahl, K. Jensen, J. M. Carstensen, and K. Conradsen, Meat Science, 102, 1-7 (2015)

11. P. Patriani, T. H. Wahyuni and T. V. Sari. Effect of Gelugur acid extract (Garcinia atroviridis) on the physical quality of culled chicken meat at different shelf life. IOP Conf. Series: Earth and Environmental Science 782022092 (2021)

12. P. Patriani, H. Hafid, T. H Wahyuni and T. V. Sari. Physical quality improvement of culled chicken meat with marinated technology using Gelugur acid (Garcinia 
atroviridis) biomass. IOP Conf. Series: Earth and Environmental Science 749012001 (2021)

13. R. Yulistiani, Jurnal Teknologi Pertanian, 11, 27-36 (2012)

14. A. M Pearson and T.R Dutson. HACCP in Meat, Poultry, and Fish Processing. (Springer, Boston, 1995)

15. M. C. Bourne. Food Texture and Viscosity 2nd Edition. (Academic Press an Elsevier Science, London, 2002)

16. M. Serdaroğlu, Ö. Değırmencioğlu, Meat Science, 68, 291-296 (2014)

17. J. K. Cisowska, E. Flaczyk, M. Rudzińska, D. Kmiecik, Meat Science, 97, 174-180 (2014)

18. A. K. Das, V. Rajkumar and D. K. Dwivedi, International Food Research Journal. 18, 563-569 (2011)

19. Z. O. Demirci, I. Y1lmaz, and A. S. Demirci, Journal of food science and technology, 51, 936-942 (2014)

20. M. K. Morsya, E. Mekawi, and R. Elsabagh, LWT - Food Science and Technology, 89, 489-495(2018)

21. I.Y1lmaz, O. Daglioglu, Meat Science, 65, 819-823 (2003)

22. A. Safrijal, Razali, Ismail, T. R. Ferasyi, Nurliana, and D. Masyitha, Jurnal Medika Veterinaria, 11, 82-87 (2017)

23. P. Patriani, E. Mirwandhono, T. H Wahyuni, G. A. W Siregar, U. Hasanah, Hasnudi, N. Ginting, and Yunilas, Journal of Physics: Conference Series, 1542 , 012029 (2020) 